\title{
Tindakan Benturan Kepentingan Yang Dilakukan Oleh Direksi Perusahaan Sebagai Bentuk Pelanggaran Prinsip Good Corporate Governance
}

\author{
Dhita Destria \\ Magister Ilmu Hukum, Universitas Indonesia \\ Email: dhitadestria94@gmail.com
}

\begin{abstract}
Abstrak. seluruh prinsip Good Corporate Governance dapat menunjang terwujudnya Good Corporate Governance dalam rangka mencegah penyalahgunaan kekuasaan dan perbuatan melawan hukum yang dilakukan oleh organ-organ perseroan. Tuntutan yang dihadapi perseroan terbatas adalah mengenai transaksi yang dilakukan oleh organ-organnya, khususnya oleh direksi perseroan terbatas dengan pihak lain yang mempunyai hubungan dekat dengan direksi perseroan terbatas tersebut yang menimbulkan benturan kepentingan. Bahwa tindakan seperti self dealing, menerima hadiah atau manfaat termasuk segala bentuk penyuapan dan kick-back fee, menjajakan pengaruh (influence pedding), memanfaatkan aset perseroan untuk kepentingan pribadi (using employer's propety for private advantage) dan memanfaatkan informasi rahasia (using confidential information) merupakan beberapa bentuk Benturan Kepentingan. Faktor-faktor yang menimbulkan Benturan Kepentingan adalah faktor internal yaitu merupakan transaksi Benturan Kepentingan dilakukan di dalam peseroan untuk kepentingan pribadi yang dilakukan oleh direksi, sedangkan faktor eksternal merupakan transaksi Benturan Kepentingan dilakukan oleh direksi untuk keuntungan pribadinya sendiri bukan untuk keuntungan perseroan, melainkan dilakukannya secara diam-diam dan kolusi.
\end{abstract}

Kata Kunci: Good Corporate Governance, Benturan Kepentingan, Direksi.

Abstract. All principles of Good Corporate Governance can support the realization of Good Corporate Governance in order to prevent abuse of power and illegal acts committed by the organs of the company. Demands faced limited liability company is about transactions conducted by the relevant organs, in particular by the board of directors of a limited liability company with others having a close relationship with the board of directors of a limited liability company that raises a conflict of interest. That actions such as self dealing, accepting gifts or benefits include all forms of bribery and kick-back fee, peddling influence (influence pedding), utilizing company assets for personal benefit (using employer's propety for private advantage) and take advantage of confidential information (using confidential information) is some form of Conflict of Interest. Factors that cause the Conflict of Interest is the internal factors are derived from transactions Conflict of Interest is done inside the company may for personal benefit of its board of directors, while external factors are transactions Conflict of Interest made by the board of directors to gain own private not for profit company, but do it in silence and collusion.

Key Words: Good Corporate Governance, Conflict of Interest, Directors.

\section{PENDAHULUAN}

Peran Direksi dalam suatu perusahaan sangatlah penting terutama dalam mengurus jalannya perusahaan tersebut. Direksi yang menjalankan peran dan tugasnya dengan baik akan berpengaruh baik pula terhadap tujuan perusahaan, begitupula sebaliknya jika Direksi dalam menjalankan peran dan

Jurnal Ilmu Sosial dan Pendidikan tugasnya tidak sesuai dengan ketentuan dan kaidah yang berlaku, maka perusahaan tersebut akan menciptakan pengelolaan perusahaan yang kurang baik.

Suatu perusahaan dalam menjalankan bisnisnya perlu menerapkan prinsip-prinsip tata kelola perusahaan yang baik sebagaimana diatur dalam Peraturan Menteri Badan Usaha 
Milik Negara Nomor PER-01/MBU/2011 Tentang Penerapan Tata Kelola Perusahaan yang Baik (Good Corporate Governance) Pada Badan Usaha Milik Negara. Direksi yang bertugas untuk menjalankan pengurusan Perseroan diharapkan mampu untuk menjalankan tata kelola perusahaan sesuai ketentuan yang berlaku.

Sebagai pengurus Perseroan, Direksi mempunyai peran yang sangat penting, selain dengan peran yang penting tersebut, Direksi juga mempunyai kekuasaan dalam melakukan tindakan dan dengan kekuasaannya itu pasti ada kemungkinan tindakan yang dilakukan oleh Direksi menyebabkan kerugian Perseroan.

Salah satu contoh yang merupakan pelanggaran prinsip Good Corporate Governance dalam bentuk tindakan benturan kepentingan adalah dalam kasus yang dilakukan Direktur PT Energy Management Indonesia (Persero) yakni perusahaan Badan Usaha Milik Negara (BUMN) sebagaimana telah diputus dengan Putusan Nomor 54/Pid.Sus-TPK/2018/PN.Jkt.Pst tanggal 21 Nopember 2018 pada tingkat pertama, dan diputus dengan Putusan Nomor 7/PID.SUSTPK/2019/PT.DKI pada tingkat banding, terjadi pelanggaran prinsip Good Corporate Governance, salah satu tindakan yang dilakukan Direksi tersebut adalah melakukan tindakan benturan kepentingan.

Direksi PT Energy Management Indonesia (Persero) melakukan kerjasama dengan PT Gaung Bakti Utama dalam kegiatan Earth Day 2015, dimana seharusnya PT Energy Management Indonesia (Persero) lah yang mengerjakan dan menerima pembayaran atas kegiatan Earth Day 2015 akan tetapi PT Energy Management Indonesia (Persero) yang mengeluarkan sejumlah uang dan digunakan oleh PT Gaung Bakti Utama dan belakangan kegiatan Earth Day 2015 dibatalkan dan tidak ada pertanggungjawaban dari PT Gaung Bakti Utama. Sebelum dilakukannya kerjasama dimaksud, PT. Energy Management Indonesia (Persero) tidak melakukan kajian bisnis, dimana seharusnya sebelum kontrak ditandatangani, PT. Energy Management Indonesia (Persero) Jurnal Ilmu Sosial dan Pendidikan harus melakukan kajian bisnis yang dilakukan oleh Direktur Pemasaran tetapi karena Direktur Pemasaran belum ada, maka yang melakukan kajian bisnis dilakukan langsung oleh Direksi yang bersangkutan selaku Direktur PT. Energy Management Indonesia (Persero). Oleh karena PT Gaung Bakti Utama adalah perusahaan yang dijalankan oleh Isteri dari Direksi PT Energy Management Indonesia (Persero), hal tersebut melanggar Pasal 23 Peraturan Menteri Badan Usaha Milik Negara Nomor PER01/MBU/2011 Tentang Penerapan Tata Kelola Perusahaan yang Baik (Good Corporate Governance) Pada Badan Usaha Milik Negara yang berbunyi "Para anggota Direksi dilarang melakukan tindakan yang mempunyai benturan kepentingan, dan mengambil keuntungan pribadi baik secara langsung maupun tidak langsung dari pengambilan keputusan dan kegiatan BUMN yang bersangkutan selain penghasilan yang sah".

Pengelolaan perusahaan yang baik saat ini merupakan suatu hal yang sudah menjadi kewajiban bagi setiap manajemen dalam menjalankan perusahaan yang dipimpinnya. Salah satu organ perusahaan yang berperan penting dalam menciptakan dan menjalankan pengelolaan perusahaan yang baik adalah Direksi perusahaan.

Perusahaan Badan Usaha Milik Negara seharusnya menerapkan prinsipprinsip GCG berdasarkan Peraturan Menteri Badan Usaha Milik Negara Nomor Per-01/MMBU/2011 tentang Penerapan Tata Kelola Perusahaan yang Baik (Good Corporate Governance) Pada Badan Usaha Milik Negara pada Pasal 2 yang memuat hal-hal sebagai berikut:

1. BUMN wajib menerapakan GCG secara konsisten dan berkelanjutan dengan berpedoman pada Peraturan Menteri ini dengan tetap memperhatikan ketentuan, dan norma yang berlaku serta anggaran dasar BUMN.

2. Dalam rangka penerapan GCG sebagaimana diamaksud pada ayat (1), Direksi menyusun GCG manual yang diantaranya dapat memuat board manual, 
Manajemen Risiko Manual, Sistem Pengendalian Intern, Sistem Pengawasan Intern, mekanisme pelaporan atas dugaan penyimpangan pada BUMN yang bersangkutan, Tata Kelola Teknologi Informasi,dan Pedoman Perilaku Etika (Code of Conduct).

3. Prinsip-prinsip GCG meliputi transparansi, kemandirian, akuntabilitas, pertanggung jawaban, dan kewajiban.

Prinsip-prinsip tersebut diatas harus dijalankan dengan baik oleh organ perusahaan terutama Direksi dalam menjalankan pengurusan perusahaan.

Direksi menjalankan pengurusan Perseroan untuk kepentingan Perseroan dan sesuai dengan maksud dan tujuan Perseron, Direksi berwenang menjalankan kepengurusan sebagaimana dimaksud sesuai dengan kebijakan yang dipandang tepat dalam batas yang ditentukan oleh undang-undang.

Perusahaan yang berkaitan dengan Badan Usaha Milik Negara dilakukan oleh Direksi, Direksi bertanggung jawab penuh secara hukum atas pengurusan perusahaan untuk kepentingan dan tujuan Perusahaan serta mewakili perusahaan baik diluar maupun diluar pengadilan. Dalam melaksanakan tugasnya Anggota Direksi harus mematuhi Anggaran Dasar Perusahaan dan peraturan perundang-undangan serta wajib melaksanakan kaidah Tata Kelola Perusahaan Yang Baik Good Corporate Governance yaitu Profesionalisme, efisiensi, transparansi, kemandirian, akuntabilitas, pertanggung jawaban serta kewajaran.

Direksi adalah pihak yang paling penting memiliki peran penting, baik dalam mengatur perusahaan, mengelola, maupun untuk memajukannya, oleh sebab itu Direksi wajib diangkat oleh Rapat Umum Pemegang Saham.

Tujuan Perseroan Terbatas (PT) akan dapat dicapai, apabila organ perusahaan dalam mengelola perusahaannya melaksanakan Prinsip-Prinsip Tata Kelola Perusahaan yang Baik (Good Corporate Governance Principle). Kemampuan bersaing dan kesuksesan suatu korporasi merupakan hasil kerja sama yang terwujud dari berbagai Jurnal Ilmu Sosial dan Pendidikan pihak yang telah memberikan kontribusi dan sumber daya, baik berupa kapital, menejemen, ketrampilan, keahlian, jasa, produk, dan lain-lain. Atas dasar inilah perseroan hendaknya mengenali dengan baik kontribusi dari masing-masing pemangku kepentingan, baik itu investor, karyawan, kreditur, pemasok, pelanggan maupun regulator yang semunya disebut sebagai stakeholders.

Pada suatu badan hukum seperti perseroan terbatas melakukan aktivitas kegiatan usahanya dilakukan oleh organ. Organ perusahaan ini terdiri dari direksi, komisaris dan pemegang saham. Prinsipprinsip Good Corporate Governance yang terdiri dari transparansi (transparency), kewajaran (fairness), akuntabilitas (accountability) dan responsibilitas (responcibility) dapat dilaksanakan apabila yang bertugas mengelola perusahaan, yakni direksi dan komisaris sebagai organ perseroan, menjalankan tugas dan fungsinya dengan itikad baik dan penuh tanggungjawab untuk tujuan perseroan.

\section{Rumusan Masalah}

Berdasarkan fakta yang telah dipaparkan di atas, penulis merasa perlu untuk melakukan penulisan artikel ilmiah dengan judul Tindakan Benturan Kepentingan Yang Dilakukan oleh Direksi Perusahaan Sebagai Bentuk Pelanggaran Prinsip Good Corporate Governance. Dengan fokus pada rumusan permasalahan : bagaimana pentingnya penerapan prinsip-prinsip Good Corporate Governance dalam perusahaan untuk mencegah terjadinya tindakan benturan kepentingan yang dilakukan oleh Direksi Perusahaan?

\section{Tujuan dan Manfaat Penelitian}

1. Tujuan Penelitian

Penelitian ini bertujuan untuk mengetahui, menganalisis dan memahami pentingnya penerapan prinsip-prinsip Good Corporate Governance dalam perusahaan untuk mencegah terjadinya tindakan benturan kepentingan yang dilakukan oleh Direksi Perusahaan.

2. Manfaat Penelitian 
Penelitian ini mempunyai manfaat teoritis dan praktis. Secara teoritis penelitian ini diharapkan memberikan kontribusi dalam perkembangan ilmu pengetahuan hukum, terutama bidang hukum ekonomi dan hukum perusahaan khususnya mengenai prinsip Good Corporate Governance. Sedangkan secara praktis, hasil penelitian ini dapat digunakan sebagai sumber kajian ilmu pengetahuan bagi masyarakat umum pada umumnya dan kepada akademisi pada khususnya.

\section{HASIL PENELITIAN DAN PEMBAHASAN \\ 1. Ketentuan Prinsip-Prinsip Good Corporate Governance dalam Perusahaan}

Tujuan Perseroan Terbatas (PT) akan dapat dicapai, apabila organ perusahaan dalam mengelola perusahaannya melaksanakan PrinsipPrinsip Tata Kelola Perusahaan yang Baik (Good Corporate Governance Principle). Kemampuan bersaing dan kesuksesan suatu korporasi merupakan hasil kerja sama yang terwujud dari berbagai pihak yang telah memberikan kontribusi dan sumber daya, baik berupa kapital, menejemen, ketrampilan, keahlian, jasa, produk, dan lain-lain. Atas dasar inilah perseroan hendaknya mengenali dengan baik kontribusi dari masing-masing pemangku kepentingan, baik itu investor, karyawan, kreditur, pemasok, pelanggan maupun regulator yang semunya disebut sebagai stakeholders.

Sebagai salah satu pilar utama dalam perseroan, tanpa adanya Direksi suatu PT tidak akan dapat menjalankan kegiatannya, dapat diketahui bahwa perseroan dianggap sekan-akan sebagai subjek hukum, di mana perseroan tidak dapat berbuat apa-apa tanpa adanya bantuan anggota Direksi sebagai manusia pribadi yang bertindak mewakili PT.

\section{Good Corporate Governance}

(GCG) secara definitive merupakan sistem yang mengatur dalam mengendalikan perusahaan untuk menciptakan nilai tambah (valueadded) untuk semua stakeholder. Konsep Good Corporate Governance (GCG) di Indonesia dapat diartikan sebagai konsep pengelolaan perusahaan yang baik. Ada dua hal yang ditekankan dalam konsep ini. Pertama, pentingnya hak pemegang saham untuk memperoleh informasi denganbenar (akurat) dan tepat pada waktunya. Kedua, kewajiban perusahaan untuk melakukan pengungkapan (disclosure) secara akurat, tepat waktu, dan transparan terhadap semua informasi kinerja perusahaan, kepemilikan, dan stakeholder.

Stakeholders merupakan setiap pihak yang memiliki kepentingan dengan kinerja perusahaan. Secara teoritis, stakeholder dapat dibagi menjadi dua, yaitu :

a. Primary stakeholder, yaitu para pemegang saham, investor karyawan dan manajer, supplier, rekanan bisnis, dan masyarakat;

b. Secondary stakeholder, yaitu pemerintah, institusi bisnis, kelompok sosial kemasyarakatan, akademisi, dan pesaing.

Suatu sistem corporate governance yang efektif harus mampu memberikan insentif yang memadai bagi Komisaris dan Direksi untuk mencapai tujuan perusahaan demi kepentingan perusahaan dan para pemegang sahamnya. Sistem ini juga harus mampu memfasilitasi adanya pengawasan yang efektif, sehingga mendorong perusahaan untuk menggunakan sumber daya perusahaan yang ada dengan lebih efisien.

a. Memaksimalkan nilai perseroan dan nilai perseroan bagi pemegang saham dengan cara meningkatkan prinsip keterbukaan, akuntabilitas, dapat dipercaya, bertanggung jawab, dan adil agar perusahaan memiliki daya saing yang kuat;

b. Mendorong pengelolaan perseroan secara profesional, transparan, dan efisien; dan 
c. Mendorong agar pemegang saham, anggota dewan komisaris dan anggota Direksi dalam membuat keputusan dan menjalankan tindakan dilandasi nilai moral yang tinggi dan kepatuhan terhadap peraturan perundangundangan serta bertanggung jawab terhadap pihak-pihak lain yang berkepentingan.

Direksi adalah organ perseroan yang diberikan kewenangan beradilan. Direksi adalah satu organ yang melaksanakan fungsi pengurusan perseroan dan bertanggung jawab untuk kepentingan dan tujuan perseroan. Selanjutnya menurut Pasal 97 ayat (3) Undang-Undang No. 40 Tahun 2007 tentang Perseroan Terbatas, anggota direksi harus bertanggung jawab atas kerugian perseroan yang timbul akibat kesalahan atau kelalaiannya dalam menjalankan tugas pengurusan. Dalam kaitan dengan tanggung jawab direksi ini, Dunfee et al., dengan tegas mengatakan bahwa:

"Corporate officials clearly do have a responsibility to follow both general laws and the specifics statutes under which their corporation was formed and operates. Thus, if, with or without guilty intent, the involve the corporation in an illegal act or one which is ultra vires-they may be held personally liable for any damage that result."

Penyalahgunaan perseroan, posisi direksi dan komisaris perseroan, pemegang saham mayoritas, terjadinya kolusi dan benturan kepentingan (conflict of interest) serta korupsi adalah hal-hal yang banyak terjadi pada tubuh perseroan. Tidak dapat diingkari bahwa semua persoalan tersebut antara lain disebabkan oleh tidak dihormatinya prinsip-prinsip good corporate governance. Hasil pengamatan ini bukanlah suatu penyederhanaan soal yang berlebihan, tetapi korupsi, kolusi, nepotisme, benturan kepentingan, dan sebagainya adalah hal-hal yang menyimpang dari cara-cara berusaha yang baik seperti yang diatur didalam peraturan perundangan dan akta perseroan.

Prinsip-prinsip GCG yang lebih umum yang ditemukan dalam UndangUndang No. 40 Tahun 2007 tentang Perseroan Terbatas, salah satunya yakni prinsip Kemandirian (independency) yang ditemukan pada:

a. Larangan kepemilikan saham silang (cross holding), baik secara langsung maupun tidak langsung dengan beberapa pengecualian; (Pasal 36 ayat (1) UU PT).

b. Larangan bagi anggota Direksi, Dewan Komisaris dan karyawan perseroan untuk menjadi kuasa pemegang saham dalam RUPS terkait pemungutan suara; (Pasal 85 ayat (4) UU PT).

c. Larangan adanya benturan kepentingan dalam melakukan tindakan pengurusan perseroan dan sanksi apabila ternyata menimbulkan kerugian, serta larangan bagi Direksi yang mempunyai benturan kepentingan untuk mewakili perseroan; (Pasal 97 ayat (5) huruf c dan 99 ayat (1) huruf b UU PT).

d. Kewajiban setiap anggota direksi untuk melaporkan pemilikan saham miliknya dan keluarganya untuk menghindari benturan kepentingan dengan konsekuensi pertanggungjawaban pribadi jika tidak dipatuhi. (Pasal 101 ayat (1) UU PT).

Kepengurusan pada perseroan dijalankan oleh direksi (pasal 92-107 UU No 40 Tahun 2007 tentang Perseroan Terbatas), rincian dari lingkup kerja dan tanggung jawab direksi ini diatur secara lebih spesifik di dalam akta perseroan, sehingga praktis sebetulnya direksi tidak dapat menyimpang dari semua prinsipprinsip hukum yang mendasari terjadinya good corporate governance.

Pelaksanaan corporate governance di Indonesia tergolong masih sangat rendah, hal ini terutama disebabkan oleh kenyataan bahwa perusahaan-perusahaan 
di Indonesia belum sepenuhnya memiliki corporate culture sebagai inti dari corporate governance. Pemahaman tersebut membuka wawasan bahwa korporat belum dikelola dengan benar dan belum menjalankan governasi. Kemudian etika menjadi penting dalam sebuah tata kelola perusahaan. Melalui internalisasi etika pada praktik tata kelola perusahaan diharapkan dapat tercipta budaya organisasi mengedepankan transparansi, akuntabilitas, responsibilitas, independensi, dankeadilan. Jadi bila etika tidak dijalankan maka yang terjadi adalah persaingan yang tidak sehat, ketidakadilan, munculnya moral hazard, penyuapan dan perilaku menyimpang lainnya.

\section{Tindakan Benturan Kepentingan yang Dilakukan oleh Direksi Perusahaan}

Sebagai salah satunya organ perseroan yang diberikan hak dan wewenang untuk bertindak untuk dan atas nama perseroan, maka direksi berhak dan berkewajiban menjalankan perseroan termasuk pengelolaan harta kekayaan perseroan. Sebagai orang kepercayan yang diangkat oleh RUPS untuk kepentingan para pemegang saham secara keseluruhan, Direksi diharapkan dapat bertindak adil dalam memberikan manfaat yang optimum bagi pemegang saham perseroan. Sebagai trustee bagi perseroan maka selayaknya jika direksi dalam melakukan tindakan atau perbuatan yang mengatasnamakan kepentingan perseroan harus dilakukan secara benar dan tidak memihak untuk kepentingan manapun juga. Oleh sebab itu, direksi tidak boleh mempergunakan kepercayaan itu untuk dipergunakan dalam kapasitasnya untuk merugikan kepentingan satu atau lebih pemegang saham tertentu dalam perseroan meskipun tindakan yang dilakukannya tersebut baik bagi perseroan menurut pertimbangannya.

Anggota Direksi wajib menghindari terjadinya "benturan kepentingan" (conflict of interest) dalam melaksanakan pengurusan perseroan. Setiap tindakan pengurusan yang mengandung benturan kepentingan, dikategori sebagai tindakan iktikad buruk (bad faith). Sebab tidankan yang demikian melanggar kewajiban kepercayaan (breach of his fiduciary duty) dan kewajiban menaati peraturan perundang-undangan.

Seorang Direktur perseroan dikatakan telah mempunyai Benturan Kepentingan, jika terjadi hal-hal sebagai berikut :

1. Berperkara di pengadilan mewakili perseroan, tetapi pihak lawan ada hubungannya dengan Direktur.

2. Seorang Direktur tidak boleh mengambil keuntungan-keuntungan tersembunyi atau terselubung dari suatu transaksi perseroan (Corporate Opportunity).

3. Terjadinya transaksi untuk pribadi (Self Dealing).

4. Seorang Direktur dalam menjalankan tugasnya di Perseroan tidaklah boleh melakukan Benturan Kepentingan, sebab, jika terjadi tindakan Direktur disangsikan tidak objektif lagi dan tidak melaksanakan kepentingan Perseroan. Karena itu, jika seseorang melakukan transaksi yang mengandung Benturan Kepentingan dikatakan bahwa Direktur tersebut telah melanggar prinsip fiduciary duties yang berlaku kepadanya.

Undang-undang PT menentukan bahwa anggota Direksi tidak berwenang mewakili perseroan apabila :

1. Terjadi perkara di depan pengadilan antara perseroan dengan anggota Direksi bersangkutan; atau

2. Anggota Direksi yang bersangkutan mempunyai kepentingan yang bertentangan dengan kepentingan perseroan.

Di dalam anggaran dasar ditetapkan yang berhak mewakili perseroan apabila terdapat benturan kepentingan dari 
anggota Direksi, akan tetapi dalam anggaran dasar tidak menetapkan hal tersebut, maka RUPS dapat mengangkat 1 (satu) orang pemegang saham atau lebih untuk mewakili perseroan, di samping itu Komisaris juga diangkat untuk melaksanakan tugas tersebut, karena Komisaris pun dapat ditunjuk oleh Rapat Umum Pemegang Saham (RUPS) atau anggaran dasar untuk menjalankan tugastugas tertentu dari perseroan.

Pada umumnya pemegang saham independen adalah pemegang saham publik atau pemegang saham minoritas yang harus mendapatkan perlindungan hukum, dan Peraturan Bapepam Nomor IX.E.1. merupakan penghormatan hak dan perlindungan kepentingan pemegang saham minoritas. Ketentuan mengenai transaksi benturan kepentingan tertentu menunjukkan bahwa peraturan UUPT menjunjung hak dan perlindungan pemegang saham suatu perseroan berdasarkan asas kesetaraan. Setiap pemegang saham secara hukum dinyatakan berhak untuk ikut menentukan kebijakan perseroan berkaitan dengan pengambilan keputusan dalam RUPS yang teramat penting dan membawa bagi kepentingan pemegang saham.

Secara prinsip Peraturan Bapepam Nomor IX.E.1. ini bertujuan, sebagai berikut :

1. Melindungi kepentingan pemegang saham independen yang umumnya merupakan pemegang saham minoritas dari perbuatan yang melampaui kewenangan Direksi dan Komisaris serta pemegang saham utama dalam melakukan transaksi benturan kepentingan tertentu.

2. Mengurangi kemungkinan penyalahgunaan kekuasaan oleh Direksi, Komisaris atau pemegang saham untuk melakukan transaksi yang mengandung benturan kepentingan tertentu.

3. Melaksanakan prinsip kerterbukaan dan penghormatan terhadap hak pemegang saham berdasarkan asas kesetaraan, persetujuan pemegang saham independen yang mewakili lebih dari $50 \%$ saham yang ada merupakan keharusan.

Faktor-faktor yang timbul dari benturan kepentingan yang dilakukan Direktur secara langsung maupun tidak langsung, sebagai berikut :

a. Faktor Internal.

Transaksi benturan kepentingan dilakukan di dalam peseroan untuk kepentingan perseroan yang dilakukan oleh Direktur, dimana transaksi benturan kepentingan tertentu tetap dapat dilakukan dan sah bila mengikuti Peraturan IX.E.1 angka 2 yaitu : "harus terlebih dahulu mendapat persetujuan oleh pemegang saham independen". Peraturan Nomor IX.E.1 angka 9 dan 10 mensyaratkan bahwa RUPS untuk transaksi yang benturan kepentingan dapat dilakukan sampai 3 (tiga) kali, sebagai berikut :

1. RUPS Pertama : a. Harus dihadiri pemegang saham independen yang mewakili lebih dari $50 \%$ saham yang dimiliki oleh pemegang saham independen. b. Harus disetujui oleh pemegang saham independen yang mewakili lebih dari $50 \%$ saham pemegang saham indepeden.

2. Dalam hal RUPS pertama tidak tercapai korum, maka RUPS kedua harus segera dilakukan, adalah : a. Dihadiri oleh pemegang saham independen yang mewakili oleh saham yang dimiliki oleh pemegang saham independen. b. Disetujui oleh pemegang saham independen yang mewakili lebih dari $50 \%$ saham yang dimiliki oleh pemegang saham independen. c. Pemberian suara dapat dilakukan langsung oleh pemegang saham atau kuasanya.

3. Dalam hal korum RUPS kedua tidak tercapai, maka RUPS ketiga harus dilakukan, RUPS, adalah: a. Mendapatkan persetujuan dari Bapepam. b. Telah diumumkan kepada masyarakat. c. Disetujui pemegang 
saham independen yang mewakili lebih dari $50 \%$ saham yang dimiliki oleh pemegang saham independen yang hadir.

Jika dalam RUPS yang ketiga tidak juga mendapat persetujuan pemegang saham independen, maka transaksi tidak boleh diajukan kembali dalam jangka waktu 12 bulan sejak tanggal penolakan.

Setiap rencana transaksi yang mengandung benturan kepentingan, harus diungkapkan terlebih dahulu, karena informasi itu merupakan panduan penting bagi pemegang saham atau investor, untuk mengambil keputusan. Semua transaksi yang tersebut harus diungkapkan dua hari hari setelah transaksi dilakukan.

b. Faktor Eksternal.

Transaksi benturan kepentingan dilakukan oleh Direktur untuk keuntungan pribadinya sendiri bukan untuk keuntungan perseroan, melainkan dilakukannya secara diam-diam, dimana perbuatan yang tidak dilandasi itikad baik oleh Direktur tadi, seperti contoh :

1. Tindakan anggota Direktur yang mengakibatkan perseroan membeli barang atau tanah dan bangunan dari pihak lain dengan harga yang lebih tinggi dari harga yang wajar, atau menjual harta kekayaan perseroan kepada pihak lain dengan harga yang jauh lebih rendah dari harga yang wajarnya, sehingga Direktur tadi memperoleh keuntungan pribadi dari transaksi tersebut, maka hal itu merupakan salah satu perbuatan yang tidak dilandasi dengan itikad baik.

2. Transaksi self dealing yang tidak langsung dan keuntungannya untuk kepentingan Direktur sendiri yang semua dilakukan dengan diam-diam dan berkolusi misalnya:
a) Transaksi antara anggota famili dan teman-temannya dari Direksi dengan perseroan.
b) Transaksi antara 2 (dua) perseroan dengan Direktur yang sama.

c) Transaksi antara perseroan dengan perseroan yang lain dalam perusahaan mana pihak mempunyai kepentingan finansial tertentu yang dilakukan oleh Direktur secara pribadi.

d) Transaksi antara perusahaan induk (holding) dengan anak perusahaan.

e) Transaksi orang dalam (Insider Trading) di dalam perseroan yang dilakukan oleh Direktur secara tidak langsung.

\section{KESIMPULAN}

Adanya transaksi benturan kepentingan yang dilakukan oleh Direksi perusahaan akan menimbulkan kerugian bagi perusahaan. Dalam melaksanakan tugasnya dalam pengurusan perusahaan, Direksi harus selalu berdasarkan itikad baik dalam melakukan suatu tindakan atau keputusan.

Seluruh prinsip Good Corporate Governance dapat menunjang terwujudnya Good Corporate Governance dalam rangka mencegah penyalahgunaan kekuasaan dan mencegah perbuatan melawan hukum yang dilakukan oleh organ perusahaan seperti Direksi. Tujuan penerapan prinsip Good Corporate Governance adalah untuk menciptakan tata kelola perusahaan yang baik, sehingga organ perusahaan terutama Direksi dapat menjalankan tugas dan tanggungjawabnya sesuai dengan kaidah yang berlaku.

\section{DAFTAR PUSTAKA}

Dunfee, Thomas W. et al.. Business and Its Legal Environment, 3rd. Ed. New Jersey: Presentice. 1992.

Fuady, Munir. Doktrin-Doktrin Dalam Corporate Law Dan Eksistensinya Dalam Hukum Indonesia. Bandung: Citra Aditya Bakti. 2002.

Gregory, Holly J. and Marsha E.Simms. The Article Publishing of Corporate Governance, OECD By The The Business Sector Advisiory Group On Corporate Governance.

Hamdani. Good Corporate Governance : Tinjauan Etika dalam Praktik 
Bisnis. Jakarta: Mitra Wacana Media. 2016.

https://www.hukumonline.com/berita/baca/ho 12593/menuju-igood-corporategovernancei-i?page $=3$, Todung Mulya Lubis, Menuju Good Corporate Governance (I), Artikel, Hukumonline, di akses pada tanggal 15 Oktober 2020.

Indonesia. Keputusan Ketua Badan Pengawas Pasar Modal Nomor KEP32/PM/2000 Tentang Perubahan Peraturan Nomor IX.E.1 tentang Benturan Kepentingan Transaksi Tertentu.

Indonesia. Peraturan Menteri Negara Badan Usaha Milik Negara Nomor PER01/MBU/2011 tentang Penerapan Tata Kelola Perusahaan Yang Baik Good Corporate Governance.

Indonesia. Undang-Undang Nomor 19 Tahun 2003 tentang Badan Usaha Milik Negara.

Indonesia. Undang-Undang Nomor 40 Tahun 2007 tentang Perseroan Terbatas.

Indonesia. Undang-Undang Nomor 8 Tahun 1995 tentang Pasar Modal.

Kaihatu, Thomas S. Good Corporate Governance dan Penerpannya di Indonesia Jurnal Manajemen dan Kewirausahaan, Vol. 8, No. 1, Maret 2006. 2006.

Lipton, Philip dan Abraham Herzberg. Understanding Law Book. Sydney: Lawbook Co. 2004.
Nasarudin, Irsan dan Indra Surya. Aspek Hukum Pasar Modal Indonesia. Jakarta: Kencana. 2004.

Saliman, R. Hukum Bisnis Perusahaan Teori Dan Contoh Kasus. Jakarta: PT Kencana. 2005.

Sembiring, Sentosa. Hukum Perusahaan Tentang Perseroan Terbatas. Bandung: Nuansa Aulia. 2007.

Surya, Indra dan Ivan Yustiavandana. Penerapan Good Corporate Governance: Mengesampingkan Hak-Hak Istimewa Demi Kelangsungan Usaha. Jakarta: Kencana. 2006.

Susilo, Leo J. dan Karlen Simarmata. Good Corporate Governance, Tanggung Jawab Direksi dan Komisaris Dalam Melaksanakannya. Bandung: Hikayat Dunia. 2007.

Tumbuan, Fred B. G. Presentation on Organs of the Perseroan Terbatas According to Law No. 40 Year 2007, makalah pada Seminar Sehari "Aspek-aspek Penting UndangUndang No. 40/2007 tentang Perseroan Terbatas", Diselenggarakan oleh Peradi (Perhimpunan Advocat Indonesia). Jakarta. 2007.

Vanderloo, Jeremy Charles. Encouraging Corporate Governance for the Closely Held Business. Mississippi College Law Review, Volume 24, Fall 2004.

Woon, Walter. Company Law. Hongman: Fith Reprint. 1994. 